\title{
Impacts of Anthropogenic Activities on the Benthic Macroinvertebrate Assemblages During the Wet Season in Kipsinende River, Kenya
}

\author{
Masresha Birara Fekadu ${ }^{1, *}\left(\mathbb{D}\right.$, Simon Agembe $^{1}$, Clement Kiprotich Kiptum ${ }^{2}$, \\ Minwyelet Mingist ${ }^{3}$
}

\author{
${ }^{1}$ University of Eldoret, Department of Fisheries and Aquatic Sciences, Kenya \\ 2University of Eldoret, Department of Civil and Structural Engineering, Kenya \\ ${ }^{3}$ Bahir Dar University, Department of Fisheries and Aquatic Sciences, Ethiopia
}

\section{How to cite}

Fekadu, M.B., Agembe, S., Kiptum, C.K., Mingist, M. (2022). Impacts of Anthropogenic Activities on the Benthic Macroinvertebrate Assemblages During the Wet Season in Kipsinende River, Kenya. Turkish Journal of Fisheries and Aquatic Sciences, 22(6), TRJFAS18410. http://doi.org/10.4194/TRJFAS18410

\section{Article History}

Received 28 October 2020

Accepted 11 January 2022

First Online 12 January 2022

\section{Corresponding Author}

Tel.: +254746963020

E-mail: masreshabirarra@gmail.com

\section{Keywords}

Anthropogenic impacts

Macroinvertebrates

River Kipsinende

\begin{abstract}
Human activities have impacted negatively the benthic macroinvertebrate assemblage of River Kipsinende in Kenya consequently affecting the biodiversity of the area. The study assessed the impact of anthropogenic activities on benthic macroinvertebrates' assemblage in the river. Quantitative triplicate samples were collected from three different longitudinal sections along the river and four biotopes from six stations. Sample collection was done monthly from (November-December, 2019, January and March, 2020). 72 samples with 20,040 macroinvertebrate individuals belonging to 14 orders, 48 families, and 68 genera were identified. The relative abundance of Dipteran was greater than Ephemeroptera. Ephemeroptera abundance in percentage was also greater than Trichopteran and Bivalvia. The relative abundance of Dipteran and taxon group of \% EPT had an inverse relation across study sites. The highest diversity and evenness were observed in station KB and the lowest in KA. Station KC had the highest number of individuals followed by station KA and the least was at station KE. The results of the canonical correspondence analysis (CCA) shown the physico-chemical parameters were affecting the macroinvertebrates communities in the river. This study provides baseline and scientific information for the appropriate water management of freshwater streams in Kenya.
\end{abstract}

\section{Introduction}

Currently, the human population growth in the world is increasing at an alarming rate, and development facilities have been centered on freshwater habitats, because of their vital role in ecological, economic, social, and cultural functions (Reddy, 2014; Lindborg, 2015). Human activities lead to habitat degradation, changes in land use, and water use that increasingly impact the structure of biodiversity and ecosystem service provisioning in rivers (Kibena et al., 2014). In East Africa, population growth is increasing, leading to accelerated deforestation, urbanization, industrial expansion, and commercial irrigation or agricultural activities that threatening freshwater bodies (GWP, 2015), and this is true in the study area. In the recent years, agricultural activities, deforestation, logging and human settlements in the Kipsinende River catchment area have increased. According to Ding et al. (2017), these human disturbances affect taxonomic distribution, abundance, composition, richness, diversity, and the functional feeding structure of benthic invertebrate assemblages. The benthic macroinvertebrates assemblages provide reliable and relevant signals about the environmental degradation and the health status of the river (Elias et al., 2014). The main reason is that they are normally found at the bottom of a stream and less mobile. Thus, these making 
them difficult to migrate away from environmental stress (Ghosh \& Biswas, 2015). In addition, to that many recent studies suggested they have relatively short life cycles that enable quick reflection of environmental changes (Pellan \& Piscart, 2018).

Studies have not been done in the Kipsinende River to assess the distribution, composition, and abundance of benthic macroinvertebrates before. Adequate management of riverine ecosystems therefore requires monitoring, assessing, and evaluating the health of streams and river conditions, by using surveys and other direct measures to determine the anthropogenic impacts on ecosystem structure and function (Parsons et al., 2016). As stated by Lozupone et al. (2012), the diversity indices had two main assumptions. 1) stable communities have high diversity, while unstable communities have low diversity, and 2) community stability is an index of environmental quality. This idea is also supported by Lobera et al. (2017) and Sundstrom et al. (2017), the reduced diversity values are associated with environmental degradation and may result in community differences between sites over time, serving as a valuable indicator of stressors. The ShannonWiener Index $\left(\mathrm{H}^{\prime}\right)$ is currently one of the most widely used indices for the calculation and measurement of biological diversity. This study aimed to assess the impact of human activities on the Kipsinende River macrobenthic assemblage in, Kenya. The findings of this study would be a basis for further studies in the basin and would also be useful in the management of freshwater streams and other institutional stakeholders.

\section{Materials and Methods}

\section{Study Site}

The study was conducted in Kipsinende River and its two tributaries, Yatiene and Kipkwen. The River originates from Elgeyo Marakwet County and flows unidirectionally through the Kaptagat forest to Uasin Gishu County and lastly feeds into the Lake Victoria basin (Figure 1). With an average annual rainfall of 1200 $\mathrm{mm}$ to $1700 \mathrm{~mm}$ and an average annual temperature of $18^{\circ} \mathrm{C}$ (Mbaka et al., 2017). The catchment of these rivers is under pressure due to various human activities (Aura et al., 2010). Six sampling stations were selected based on the level of human interference and land-use activities such as agricultural, forested, and mixed (agricultural + forested +Cattle grazing) (Table 1). The River is used for various domestic activities such as drinking, bathing, laundry, washing of vehicles, motorbikes, cattle drinking, and to some extent irrigation purposes (personal field observation).

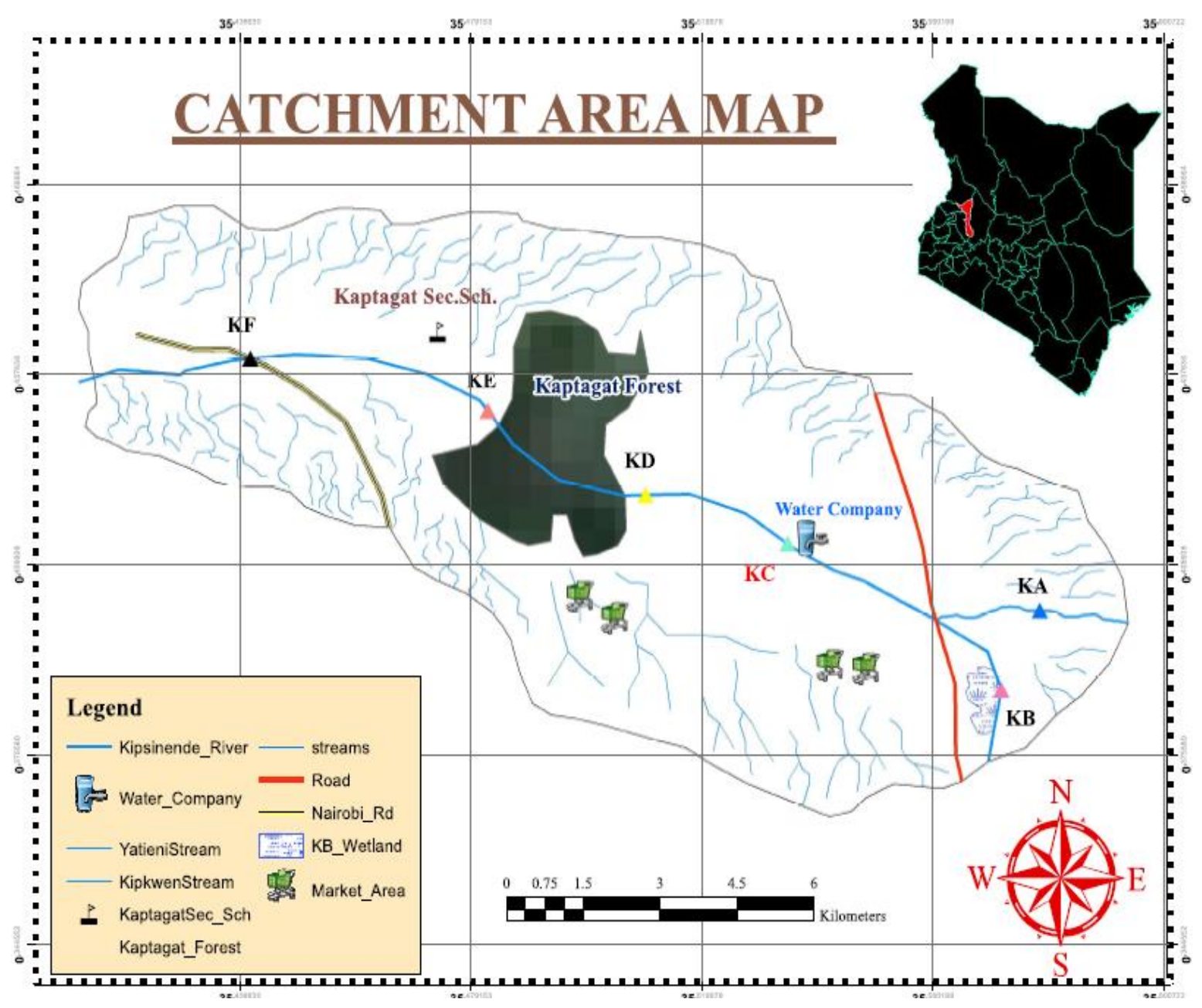

Figure 1. Map of the study area and the sampling stations (KA, KB, KC, KD, KE, and KF) during the study period in Kipsinende River 


\section{Sample Collection and Analysis}

Samples were collected for a period of 4 months (November-December, 2019, January and March, 2020) during wet season. The sampling station was selected randomly to avoid bias and covering all catchments to determine the effect of land use and human disturbances on the river ecosystem based on the accessibility factor, physical proximity, habitat diversity, and riparian land use. The benthic macroinvertebrates sampling was carried out by using a kick net $\left(1 \mathrm{~m}^{2}, 0.5\right.$ $\mathrm{mm}$ mesh size) against water current and dragged along the riverbank up to a distance of $1 \mathrm{~m}$ for all sampling stations. However, benthic macroinvertebrates in the sediment were sampled by using Ekman grabs (Ziajahromi et al., 2018). Each sampling station was marked using a Geographical Positioning System (GPS) to be sure that samples were collected from the same place at each sampling time. To obtain representative data, quantitative triplicate samples were collected from three different longitudinal sections along the river (upstream, midstream, and downstream) and four biotopes (runs, riffles, pools, and marginal vegetation) from each station.

Visible organisms were removed with forceps from the substrate and put into the specimen bottles and preserved with $4 \%$ formalin in the field until laboratory analysis had been performed (Alonso \& Camargo, 2010). The specimen bottles were well labeled twice for better and reliable information. In the laboratory, samples were washed through a $300 \mu \mathrm{m}$ mesh size sieve, using tap water and sorted in a white plastic tray. After sorting and identification were done, the organisms were preserved in a vial containing $70 \%$ ethanol. The identification was done at the Genus level using a dissecting microscope and appropriate keys (Gerber \& Gabriel, 2002; Merritt et al., 2008) in the laboratory of fisheries and aquatic science department, University of Eldoret.

Water quality parameters such as water ambient temperature, dissolved oxygen (DO), power of hydrogen $(\mathrm{pH})$, total dissolved solids (TDS), conductivity, and salinity were measured in-situ using YSI 556 MPS portable multi-parameter. For laboratory analysis, 1 liter of water sample was collected for determining the concertation of nitrates, nitrites, ammonia, and soluble reactive phosphate and carried out according to APHA (1998).

\section{Data Analysis}

The benthic macroinvertebrate indices of abundance, composition, diversity, richness, evenness, equitability, and dominance were determined by enumeration, number of taxa, and the total number of individuals, by calculation and use various indices (Shannon-Weaver diversity index, Simpson's diversity index, and Margalef richness index). Composition measures like \%EPT was calculated as: \%EPT $=[(E+P+T)$ $* 100] / N$ where, $E=T$ The number of Ephemeroptera, $\mathrm{P}=$ The number of Plecoptera, $\mathrm{T}=$ The number of Trichoptera and $\mathrm{N}=$ Total number of individuals in a station.

Water quality parameters were analyzed by using descriptive statistics and presented as mean, and Standard Error (mean \pm SE). Pearson correlation coefficient was carried out to determine the relationships between each water quality parameter. One-way analysis of variance (ANOVA) was used to evaluate the differences in the means of water quality parameters and abundance of macroinvertebrates at a 95\% level of significance and followed by Post hoc Turkey's honest significance differences (HSD) tests. Canonical correspondence analysis (CCA) was also applied to evaluate the relationship between benthic macroinvertebrate community and Physico-chemical water parameters. Meanwhile, the abundance data of macroinvertebrates were transformed using $\log (x+1)$ before Canonical correspondence analysis was carried out to checked the statistical normality. Microsoft Exce $^{\circledast}$ and PAST v4.02 (Hammer et al., 2001) software were also used for the analysis.

\section{Results and Discussion}

\section{Macroinvertebrates Distribution, Abundance, and Composition}

From a total of 72 collected samples, 20,040 macroinvertebrate individuals belonging to 14 orders, 48 families, and 68 genera were identified and counted (Table 2). Hence, taxa abundances were much higher compared with benthic macroinvertebrates in other Kenyan rivers with similar sampling design and agroecology such as, 1499 individuals, (Aura et al., 2010) and 13 taxa, (Mbaka et al., 2014). The main taxonomic groups were Dipteran (11 families, 15 genera, 10187

Table 1. Geographical coordinates of the stations and main human activities during the study period in Kipsinende River

\begin{tabular}{|c|c|c|c|c|c|c|}
\hline \multirow{2}{*}{ Characteristics } & \multicolumn{2}{|c|}{ Upstream } & \multicolumn{2}{|c|}{ Middle stream } & \multicolumn{2}{|c|}{ Downstream } \\
\hline & Station1 & Station 2 & Station 3 & Station 4 & Station 5 & Station 6 \\
\hline Given code & KA & KB & $\mathrm{KC}$ & KD & $\mathrm{KE}$ & $\mathrm{KF}$ \\
\hline Altitude(m) & 2630 & 2613 & 2580 & 2563 & 2418 & 2392 \\
\hline Latitude(N) & $00^{\circ} 23.005^{\prime}$ & $00^{\circ} 22.117^{\prime}$ & $00^{\circ} 23.184^{\prime}$ & $00^{\circ} 23.598^{\prime}$ & $0025^{\circ} .589^{\prime}$ & $0025^{\circ} .606^{\prime}$ \\
\hline $\begin{array}{l}\text { Longitude(E) } \\
\text { Land-use type } \\
\text { Human activities }\end{array}$ & $\begin{array}{l}035^{\circ} 34.144^{\prime} \\
\text { agricultural } \\
\text { deforestation } \\
\text { agriculture }\end{array}$ & $\begin{array}{l}035^{\circ} 33.574^{\prime} \\
\text { mixed } \\
\text { grazing } \\
\text { washing }\end{array}$ & $\begin{array}{l}035^{\circ} 33.023^{\prime} \\
\text { mixed } \\
\text { grazing } \\
\text { agriculture }\end{array}$ & $\begin{array}{c}035^{\circ} 32.416^{\prime} \\
\text { mixed } \\
\text { logging } \\
\text { grazing }\end{array}$ & $\begin{array}{c}035^{\circ} 27.865^{\prime} \\
\text { forested } \\
\text { almost none } \\
\text { Or no visible impact }\end{array}$ & $\begin{array}{l}035^{\circ} 28.659^{\prime} \\
\text { mixed } \\
\text { Washing } \\
\text { Grazing }\end{array}$ \\
\hline
\end{tabular}


Table 2. List of macroinvertebrate taxa found in River Kipsinende from November 2019 to March 2020 study period ( $x=$ indicates the presence of macroinvertebrate at each station).

\begin{tabular}{|c|c|c|c|c|c|c|c|c|}
\hline \multirow[b]{2}{*}{ Order } & \multirow[b]{2}{*}{ Family } & \multirow[b]{2}{*}{ Genus } & \multicolumn{6}{|c|}{ Sampling station } \\
\hline & & & $\mathrm{KA}$ & KB & KC & $\mathrm{KD}$ & $\mathrm{KE}$ & $\mathrm{KF}$ \\
\hline \multirow[t]{15}{*}{ Diptera } & Simulidae & Simulium & $x$ & $x$ & $x$ & $x$ & $x$ & $x$ \\
\hline & Tipulidae & Tipula & $x$ & $x$ & $x$ & $x$ & $x$ & $x$ \\
\hline & & Hexatoma & & $x$ & & & & \\
\hline & & Limonia & & & & & $x$ & $x$ \\
\hline & & Antocha & & $x$ & $x$ & & $x$ & $x$ \\
\hline & Chironomidae & Tanypodinae & $x$ & $x$ & $x$ & $x$ & $x$ & $x$ \\
\hline & & Chironomus & $x$ & $x$ & $x$ & $x$ & $x$ & $x$ \\
\hline & Ceratopogonidae & Bezzia & & $\mathrm{x}$ & $x$ & $x$ & $x$ & $x$ \\
\hline & Tanyderidae & Tanyderus & $x$ & $x$ & $x$ & & $x$ & $x$ \\
\hline & Dolichopodiae & Dolichopodid & & $x$ & & & & \\
\hline & Chaoboridae & Chaoborus & $x$ & $x$ & $x$ & $x$ & & \\
\hline & Syrphidae & Syrphinae & & & $x$ & & & \\
\hline & Ephydridae & Ephydrid & $x$ & & & & & \\
\hline & Dixidae & Dixa & & & & $x$ & & \\
\hline & Musidae & Mussa & & & $x$ & & & \\
\hline \multirow[t]{10}{*}{ Ephemeroptera } & Baetidae & Baetis & $x$ & $x$ & $x$ & $x$ & $x$ & $x$ \\
\hline & & Acanthiops & $x$ & $x$ & $x$ & $x$ & $x$ & $x$ \\
\hline & & Demoreptus & & & $x$ & & & \\
\hline & & Rheoptilum & & & & & & $x$ \\
\hline & Heptagenidae & Afronurus & $x$ & $x$ & $x$ & $x$ & $x$ & $x$ \\
\hline & Caenidae & Caenis & $x$ & $x$ & $x$ & $x$ & $x$ & $x$ \\
\hline & & Afrocaenis & $x$ & $x$ & & & & $x$ \\
\hline & Leptophlebiidae & Adenophlebia & $\mathrm{x}$ & & $\mathrm{x}$ & $\mathrm{x}$ & $\mathrm{x}$ & $\mathrm{x}$ \\
\hline & Ephemerellidae & Ephemerella & $x$ & $x$ & & $x$ & & \\
\hline & Tricorythidae & Disercomyzon & & & & & $\mathrm{x}$ & $\mathrm{x}$ \\
\hline \multirow[t]{10}{*}{ Trichopetra } & Hydropsychidae & Hydropsyche & $x$ & $x$ & $x$ & $x$ & $x$ & $x$ \\
\hline & & Leptonema.sp & & & $x$ & & & \\
\hline & & Cheumatosyche & & $x$ & $x$ & $x$ & $x$ & \\
\hline & Leptoceridae & Trianodes & $x$ & $x$ & $x$ & $x$ & $x$ & $x$ \\
\hline & & leptocerus & $\mathrm{x}$ & $\mathrm{x}$ & & & & \\
\hline & & Adicella & $x$ & & & & $x$ & $x$ \\
\hline & Lepidestomatidae & Lepidostoma & & $x$ & $x$ & & $x$ & \\
\hline & Pisulidae & Pisulia & & & & $x$ & & \\
\hline & Calamocetatidae & Anisocentropus & & & & & $x$ & \\
\hline & Philopotamidae & Chimarra & & $x$ & & & $x$ & \\
\hline \multirow[t]{12}{*}{ Hemiptera } & Gerridae & urimetra & $x$ & & & & $x$ & \\
\hline & & Gerris & $x$ & & $x$ & $x$ & $x$ & $x$ \\
\hline & & Eurymetra & $x$ & & & & & \\
\hline & Hebridae & Hebrus & & $x$ & & & & \\
\hline & Nepidae & Ranatra & $x$ & $x$ & & & & \\
\hline & & boborophilus & & & $x$ & $x$ & $x$ & \\
\hline & Naucoridae & Naucoris & & & $x$ & & & \\
\hline & Veelidae & Mesovelia & $x$ & & & & $x$ & \\
\hline & Mesorehidae & Mesorehia & & & & & & $x$ \\
\hline & Corixidae & Corixa & $x$ & & $x$ & & & $\mathrm{x}$ \\
\hline & Notonectidae & Notonectha & & $x$ & $x$ & $x$ & $x$ & $x$ \\
\hline & Hydrometridae & Hydrometra & & & & $x$ & & \\
\hline \multirow[t]{8}{*}{ Coleoptera } & Gyrinidae & Orechygrus & $x$ & $x$ & & $x$ & $x$ & \\
\hline & & Orectogyrus & $x$ & $x$ & & & & \\
\hline & & Orectochilini & & & & & $x$ & \\
\hline & & Dineutus.sp & $x$ & $x$ & $x$ & $x$ & & $x$ \\
\hline & Scirtidae & Elodes & & $x$ & & & $x$ & $x$ \\
\hline & Elmidae & Elminae & $x$ & $x$ & & & $x$ & $x$ \\
\hline & Dytiscidae & Hydaticus & & $x$ & $x$ & $x$ & $x$ & \\
\hline & & Yola & & $x$ & & & & \\
\hline Decapoda & Potamonutidae & Potamonute & $x$ & $x$ & $x$ & $x$ & $x$ & $\mathrm{x}$ \\
\hline Bivalvia & Sphaeriidae & Pisidium & $x$ & $x$ & $x$ & $x$ & $x$ & $x$ \\
\hline Gastropods & Thiaridae & Thiaridae & $x$ & & & & & \\
\hline Oligochaeta & Tubificidae & Tubifex & $x$ & $x$ & $x$ & $x$ & $x$ & $x$ \\
\hline & Lumbriculidae & Lumbricus & $x$ & $x$ & & & $x$ & $\mathrm{x}$ \\
\hline Odonata & Gomphidae & Gomphus & $x$ & $x$ & $x$ & $x$ & $x$ & $x$ \\
\hline & Lestidae & Lestes & $x$ & $x$ & $x$ & $x$ & $x$ & $\mathrm{x}$ \\
\hline & Aeshnidae & Ashena & $x$ & & & & & \\
\hline Arhynchobdellida & Hirudinae & Hirudo & $x$ & $\mathrm{x}$ & $x$ & $x$ & $x$ & $\mathrm{x}$ \\
\hline Tricladida & Planariidae & Dugesia & & $x$ & & & $x$ & \\
\hline Lepidoptera & Crambidae & Paraponix & & & & $x$ & & \\
\hline & & Syndita & & & & $x$ & $x$ & \\
\hline Araneae & Dictynidae & Argyroneta & & & & & & $x$ \\
\hline Total & 48 & 68 & 37 & 40 & 34 & 32 & 40 & 34 \\
\hline
\end{tabular}


individuals 51\%), followed by the Ephemeroptera ( 6 families, 10 genera, 5457 individuals 27\%), Trichopteran ( 6 families, 10 genera, and 1123 individuals $\sim 6 \%$ ) and Bivalvia (1 family, 1 genus 1273, individuals $6 \%$ ) (Table $2 \& 3$ ). The remaining relative abundance consisted of Coleoptera, Hemiptera, Oligochaeta, Odonata, Decapoda, Arhynchobdellida, Tricladida, Lepidoptera, Gastropod and Araneae.

As mentioned above Diptera was the dominant taxonomic group during this study period. Spatially the highest relative abundance (79\%) was found in station KA (agricultural land use pattern) and the lowest (7\%) was in station KE (forested site) (Table 4 \& Figure 2). This might have been due to increased input of organic nutrients from agricultural activities, which could have possibly given the benthic macroinvertebrates communities to increase in number as well as their tolerance ability to high pollution. A similar study was done by Deborde et al. (2016), who observed that the highest abundance of benthic macroinvertebrates was found in agricultural and mixed land uses. Bartlett-Healy et al. (2012), were also reported that most of the Dipteran families such as Chironomidae, Dixidae, and Culicidae tolerate a wide range of water qualities, especially in polluted waters by using atmospheric oxygen. The four genera (Simulium, Tipula, Tanypodinae and Chironomus) under order Diptera were found in all stations.

Table 3. The abundances of orders with their significance level in each site during study period in Kipsinende River

\begin{tabular}{|c|c|c|c|c|c|c|c|c|}
\hline \multirow[t]{2}{*}{ Orders Name } & \multicolumn{6}{|c|}{ No of individuals at each site } & \multirow[t]{2}{*}{ F-Value } & \multirow[t]{2}{*}{$\mathrm{p}$-value } \\
\hline & KA & $\mathrm{KB}$ & KC & KD & $\mathrm{KE}$ & $\mathrm{KF}$ & & \\
\hline Diptera & 3584 & 310 & 3132 & 1225 & 102 & 1834 & 0.53 & 0.602 \\
\hline Ephemeroptera & 527 & 1189 & 1148 & 1100 & 759 & 734 & 0.89 & 0.436 \\
\hline Trichopetra & 40 & 310 & 393 & 273 & 60 & 47 & 1.88 & 0.195 \\
\hline Hemiptera & 16 & 32 & 10 & 19 & 24 & 4 & 0.46 & 0.641 \\
\hline Coleoptera & 16 & 31 & 10 & 42 & 8 & 9 & 1.36 & 0.294 \\
\hline Odonata & 67 & 157 & 65 & 94 & 34 & 9 & 0.50 & 0.617 \\
\hline Decapoda & 32 & 25 & 42 & 15 & 41 & 102 & 0.52 & 0.605 \\
\hline Oligochaeta & 68 & 295 & 93 & 14 & 267 & 188 & 0.41 & 0.671 \\
\hline Bivaliva & 177 & 500 & 127 & 75 & 183 & 211 & 1.05 & 0.379 \\
\hline Arhynchobdellida & 6 & 104 & 5 & 5 & 3 & 4 & 0.45 & 0.647 \\
\hline Tricladida & 0 & 6 & 0 & 0 & 1 & 0 & 0.40 & 0.681 \\
\hline Lepidoptera & 0 & 0 & 0 & 23 & 8 & 0 & 1.53 & 0.256 \\
\hline Araneae & 0 & 0 & 0 & 0 & 0 & 1 & 1.00 & 0.397 \\
\hline
\end{tabular}

Table 4. Various metric categories based on benthic macroinvertebrates taxa that were selected from November 2019 to March 2020 during the investigation period in River Kipsinende

\begin{tabular}{|c|c|c|c|c|c|c|}
\hline \multirow[t]{2}{*}{ Category } & \multirow{2}{*}{ Agricultural $\frac{\mathrm{KA}}{\mathrm{K}}$} & \multirow{2}{*}{$\begin{array}{l}\text { Mixed } \\
\text { KB }\end{array}$} & \multicolumn{3}{|c|}{ Forest } & \multirow[b]{2}{*}{$\mathrm{KE}$} \\
\hline & & & KC & $\mathrm{KD}$ & KF & \\
\hline \multicolumn{7}{|c|}{ Richness measures } \\
\hline Total No. of individuals & 4538 & 2959 & 5025 & 2885 & 3143 & 1490 \\
\hline Total No. of taxa & 37 & 40 & 34 & 32 & 34 & 40 \\
\hline No. of EPT Taxa & 11 & 12 & 11 & 10 & 11 & 13 \\
\hline No. Ephemeroptera Taxa & 7 & 6 & 6 & 6 & 8 & 6 \\
\hline No. Trichoptera Taxa & 4 & 6 & 5 & 4 & 3 & 7 \\
\hline No. Hemiptera Taxa & 6 & 3 & 5 & 4 & 4 & 5 \\
\hline No. Coleoptera Taxa & 4 & 7 & 2 & 3 & 3 & 5 \\
\hline No. Diptera Taxa & 7 & 10 & 10 & 7 & 8 & 8 \\
\hline No. Odonata Taxa & 3 & 2 & 2 & 2 & 2 & 2 \\
\hline No. Oligochaeta Taxa & 2 & 2 & 1 & 1 & 2 & 2 \\
\hline \multicolumn{7}{|c|}{ Composition measures } \\
\hline$\%$ EPT & 12 & 51 & 31 & 48 & 25 & 55 \\
\hline \% EPT: \% Diptera & 0 & 5 & 0 & 1 & 0 & 8 \\
\hline \% Ephemeroptera & 12 & 40 & 23 & 38 & 23 & 51 \\
\hline$\%$ Trichoptera & 1 & 10 & 8 & 9 & 2 & 4 \\
\hline$\%$ Hemiptera & 0 & 1 & 0 & 1 & 0 & 2 \\
\hline$\%$ Coleoptera & 0 & 1 & 0 & 1 & 0 & 1 \\
\hline \% Diptera & 79 & 10 & 62 & 42 & 58 & 7 \\
\hline$\%$ Odonata & 1 & 5 & 1 & 3 & 0 & 2 \\
\hline$\%$ Oligochaeta & 2 & 10 & 2 & 0 & 6 & 18 \\
\hline \multicolumn{7}{|c|}{ Dominance and diversity } \\
\hline Dominance_D & 0.61 & 0.16 & 0.31 & 0.27 & 0.35 & 0.17 \\
\hline Simpson_1-D & 0.39 & 0.84 & 0.70 & 0.73 & 0.65 & 0.83 \\
\hline Shannon_H & 1.05 & 2.39 & 1.73 & 1.75 & 1.64 & 2.28 \\
\hline Evenness_e^ $\mathrm{H} / \mathrm{S}$ & 0.08 & 0.27 & 0.17 & 0.18 & 0.24 & 0.15 \\
\hline Margalef's index (S) & 4.28 & 4.88 & 3.87 & 3.89 & 4.10 & 5.34 \\
\hline Equitability_J & 0.29 & 0.65 & 0.49 & 0.51 & 0.46 & 0.62 \\
\hline
\end{tabular}


Whereas, the highest relative abundance (55\%) for taxon groups of EPT\% (Ephemeroptera $=51 \%$, Plecoptera $=0 \%$, and Trichoptera $=4 \%$ ) were recorded in station KE and the lowest (12\%) was in station KA. The probable reason could be due to the level of water quality, habitat quality, and the availability of food. This agrees with Patrick et al. (2014), who suggested that the presence of smaller number of EPT taxa (Ephemeroptera, Plecoptera, and Trichoptera) and their individuals in most of the impacted stations indicated that there was poor water and habitat quality as well low food availability. During this study period, order Plecoptera was not found. It could have been because it belongs to groups of sensitive aquatic insects. The relative abundance of Diptera and group of \%EPT had an inverse relation at each sampling station. A similar finding was reported by Raburu et al. (2009), who observed that when the abundance of Diptera increased, the group of EPT was reduced. Baetis, Acanthiops, Afronurus, and Caenis from Ephemeroptera as well as Hydropsyche and Trianodes from Trichoptera were frequently observed in all stations. While Anisocentropus was recorded only at stations KE.

On the other hand, the order (Odonata and Hemiptera) had a higher abundance in station KA (agricultural area). Whereas, Coleoptera and Oligochaeta, had a lower abundance at station (KC and $\mathrm{KD})$. This might have the presence of relative higher pollution at each site with various human activities such as the washing of motorbikes, clothes, bathing laundry activities, grazing, animal wastes, and agricultural inputs (fertilizer, pesticides, and herbicides). Similar observations were carried out by Masese et al. (2014), Płociennik and Karaouzas (2014), Mariadoss and Ricardo (2015), who stated that the presence of a greater number of Hemipteran and Odonata might be an indication of water quality deterioration due to pollution. Based on ANOVA in (Table 3 ), there were significant differences among stations $(P<0.05)$ for taxa Odonata, Ephemeroptera, Trichopetra, Coleoptera, Tricladida and Araneae. However, in other taxonomic groups, there were no significant differences among stations $(P>0.05)$.

\section{Diversity of Macroinvertebrates}

The diversity of macroinvertebrates along with the sampling station in Kipsinende River during the study period is indicated in (Table 4). Thus, based on (Table 4) the value of the Shannon- Weiner diversity index $(H)$ in the sampling stations varied from 1.05 to 2.39 . The highest value (2.39) was observed at station KB followed by 2.28 at station KE. Whereas, the lowest (1.05) was found at station KA. This value is greater than what was reported by Mbaka et al. (2014). For their variation, the main reason could be the availability of quality and quantity of food sources, the trophic structure, and the level of environmental stress for each site. This result was agreed with Egler et al. (2012), and Lozupone et al. (2012), who stated that stable environments have high diversity, while unstable communities have low diversity. However, this idea was contrasted to Morphin-Kani \& Murugesan (2014), who suggested that the high macroinvertebrate diversity could be an indication of a stress- environment and very low diversity showing the environment is under some lack of habitat availability.

Like, Shannon-Wiener index, diversity within the macroinvertebrate community was also described using Simpson's diversity index (1-D). According to Mandeville (2002), the Simpson Index (1-D), with values ranging from 0 to 1 . The values 0 , indicating a low level of

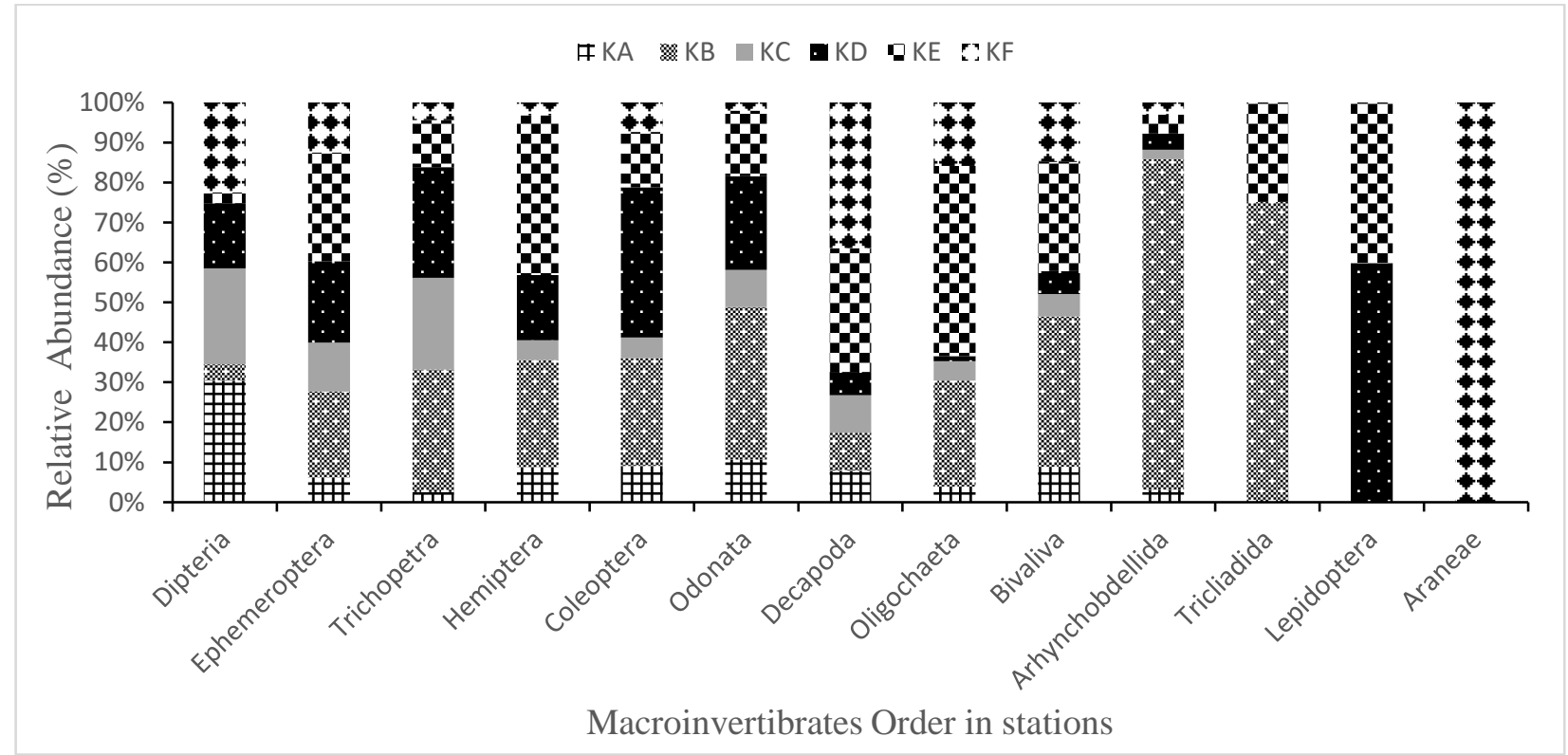

Figure 2. Overall percentage relative abundance of the macroinvertebrate order at each sampling station in River Kipsinende from November 2019 to march 2020 study period. 
diversity and 1 for a high level of diversity. Simpson's diversity index in Kipsinende River varied from 0.39 (KA) to $0.84(K B)$. The highest $(0.84)$ was observed in station $K B$ and the lowest $(0.39)$ was in $K A$. This recorded value in Kipsinende river according to the given range indicated the presence of almost a high level of diversity. The Shannon-Wiener Index $\left(\mathrm{H}^{\prime}\right)$ and Simpson's diversity index (1-D) showing the same trend at each sampling station. However, they had an inverse relation to Dominance (D). This finding was also agreed with Magurran (2013), who stated that Shannon's diversity and Simpson's diversity indices differ in their theoretical foundation and interpretation, but they have strong correlations with each other.

Margalef richness index in Kipsinende River was observed in the range of 3.87 and 5.34. Relatively the highest Margalef richness index was 5.34 followed by 4.88 and 4.28 which were found at station $K E, K B$, and $K A$, respectively. Whereas, the lowest (3.87) was recorded at station $\mathrm{KC}$. In the same way, the highest taxa richness was found in station KB (40) and station KE (40). While the lowest (32) was in station KD. The variation among sites might be due to the level of environmental stress in the area via increased human activities. This idea was verified by Andem et al. (2012), who suggested that low taxa richness may indicate the environment is seriously degraded with various anthropogenic activities. This also affected the benthic macroinvertebrate community.

The range of evenness was also varied from 0.08 to 0.27 . The highest evenness (0.27) was located at station KB and the lowest (0.08) was at station KA. This might be due to the status of water quality. This result was agreed with Dipankar and Jayanta (2015), Upen and Sarada (2015), who observed high evenness were showing poor water quality and lack of available food. The recorded value indicating that the evenness index and richness index had the same trends from station KA to KD but, at station KE and KF contrast each other. This idea disagreed with Chrisoula et al. (2011), who suggested that the increasing value for species richness index was responsible for the reduced value of the evenness index. The equitability of benthic macroinvertebrates along sampling sites was found in the range of 0.29 and 0.65 . The maximum value (0.65) was observed at station $K B$ and the minimum at $K A$. It had similar trends with the Margalef richness index at each site.

\section{Water Quality Parameters}

The mean values of each physicochemical parameters at each sampling station have been presented in (Table 5). The mean surface water temperature in study stations varied between $16.54 \pm 0.23$ and $19.17 \pm 0.43^{\circ} \mathrm{C}$. The highest value was recorded in station KD (in mixed land use) and the lowest was in station KE (in forested site). Statistically significant differences were found among stations
(ANOVA, $P<0.05)$. This could be due to the presence and absence of vegetation cover/shading effect, anthropogenic activities in the watershed, and water depth. This result agreed with Dhinamala et al. (2015), who suggested that the surface water temperature is influenced by the intensity of solar radiation, evaporation, and river water influx. However, the maximum $(8.78 \pm 0.75)$ mean concentration of dissolved oxygen was found in station KE (forested site) and the minimum (5.81 \pm 0.4 ) was in station KC (mixed land use) which indicated that temperature and dissolved oxygen had in direct relationship each other. Similar findings were reported by Vincy et al. (2012) and Deepa et al. (2016), who stated that dissolved oxygen is inversely proportional to the water temperature. Based on ANOVA there was a significant difference among stations $(P<0.05)$.

The mean concertation of $\mathrm{pH}$, total dissolved solids (TDS), total suspended solids (TSS), and conductivity were highest in station KF (downstream of the river). There were no significant differences among stations for $\mathrm{pH}, \mathrm{TSS}$, and TDS values. However, there were statistically significant differences in the value of conductivity in sampling stations. Likewise, mean concentrations of ammonia, nitrite, and soluble reactive phosphate (SRP), nitrate was higher at station KF and KB, respectively. This might have been due to agricultural fertilizer runoff, wastes from animals and humans as well as other anthropogenic activities such as washing clothes and cars which were prevalent near stations.

\section{The Relationship Between the Water Quality Parameter and Macroinvertebrates}

The relationship between the physicochemical parameter and macroinvertebrates communities illustrated in (Figure 3). The first and the second canonical axes explained $41.75 \%$ (eigenvalue of 0.066 ) and $30.18 \%$ (eigenvalue of 0.047 ) of the variation in the macroinvertebrates data respectively. The macroinvertebrates and physico-chemical correlation of the first axis were not statistically significant in a Monte Carlo permutation test $(P>0.05)$. Based on (figure 3 ) the CCA ordination showed that variation benthic macroinvertebrates communities were related to temperature, conductivity, soluble reactive phosphate, nitrate, dissolved oxygen, ammonia, and other variables. In the first axis DO, TDS, $\mathrm{pH}$, nitrite, ammonia and conductivity were positively correlated with Adenophlebia, Disercomyzon, Potamonute, Baetis, Afronurus, Caenis and Lumbricus. Benthic macroinvertebrates require the varied optimal temperature to survive (Singh \& Sharma, 2014; Prommi \& Payakka, 2015). In contrast, temperature, nitrate, salinity and soluble reactive phosphate (SRP) were negatively correlated with those macroinvertebrates. A similar result was observed in the study by Maneechan \& Prommi (2015), who stated that Baetidae negatively correlated with the concentration of phosphate. 
Table 5. Major water quality parameters with their (mean \pm SE) collected from six sampling stations from November 2019 to March 2020 study period in River Kipsinende (DO=dissolved oxygen, $\mathrm{pH}=$ power of hydrogen, TSS=total suspended solid, TDS=total dissolved solid)

\begin{tabular}{|c|c|c|c|c|c|c|c|c|}
\hline & \multicolumn{2}{|c|}{ Agricultural } & \multicolumn{2}{|c|}{ Mixed } & \multicolumn{2}{|c|}{ Forested } & \multirow[t]{2}{*}{ F-value } & \multirow[t]{2}{*}{ P-value } \\
\hline Physico-chemical & & & & & & & & \\
\hline Temperature $\left(c^{\circ}\right)$ & $16.87 \pm 0.23^{b c}$ & $17.06 \pm 0.29^{b}$ & $18.52 \pm 0.55^{a}$ & $19.17 \pm 0.43^{a}$ & $17.14 \pm 0.21^{\mathrm{c}}$ & $16.54 \pm 0.21^{b}$ & 16.34 & 0.000 \\
\hline $\mathrm{DO}(\mathrm{mg} / \mathrm{L})$ & $7.35 \pm 0.89^{\mathrm{ab}}$ & $6.71 \pm 0.62^{a b}$ & $5.81 \pm 0.4^{b}$ & $6.35 \pm 0.38^{\mathrm{ab}}$ & $8.57 \pm 0.82^{\mathrm{ab}}$ & $8.78 \pm 0.75^{a}$ & 3.23 & 0.014 \\
\hline $\mathrm{pH}$ & $7.03 \pm 0.05$ & $7.21 \pm 0.08$ & $7.02 \pm 0.03$ & $7.25 \pm 0.13$ & $7.37 \pm 0.18$ & $7.36 \pm 0.15$ & 1.71 & 0.150 \\
\hline Conductivity ( $\mu \mathrm{S} / \mathrm{cm})$ & $28.89 \pm 3.1^{b}$ & $31.78 \pm 3.03^{b}$ & $32.22 \pm 1.8^{\mathrm{b}}$ & $33.56 \pm 3.43^{\mathrm{ab}}$ & $45 \pm 2.82^{\mathrm{a}}$ & $39.4 \pm 2.19^{a b}$ & 4.26 & 0.003 \\
\hline TSS (mg/L) & $0.06 \pm 0.01$ & $0.08 \pm 0.01$ & $0.04 \pm 0.01$ & $0.06 \pm 0.01$ & $0.08 \pm 0.01$ & $0.05 \pm 0.01$ & 2.49 & 0.053 \\
\hline TDS (mg/L) & $21.27 \pm 0.65$ & $22.47 \pm 1.4$ & $22.78 \pm 1.54$ & $22.91 \pm 1.04$ & $23.41 \pm 1.22$ & $23.04 \pm 0.99$ & 1.11 & 0.367 \\
\hline \multicolumn{9}{|l|}{ Nutrients } \\
\hline Salinity(mg/L) & $0.11 \pm 0.003$ & $0.12 \pm 0.01$ & $0.13 \pm 0.01$ & $0.14 \pm 0.005$ & $0.13 \pm 0.01$ & $0.11 \pm 0.008$ & 1.95 & 0.104 \\
\hline Ammonia (mg/L) & $0.78 \pm 0.27$ & $0.41 \pm 0.16$ & $0.39 \pm 0.13$ & $0.53 \pm 0.18$ & $1.05 \pm 0.40$ & $0.58 \pm 0.15$ & 1.14 & 0.363 \\
\hline Nitrate (mg/L) & $2.09 \pm 0.14$ & $2.40 \pm 0.14$ & $1.91 \pm 0.31$ & $2.03 \pm 0.26$ & $2.16 \pm 0.07$ & $1.87 \pm 0.15$ & 0.98 & 0.448 \\
\hline Nitrite(mg/L) & $0.42 \pm 0.12$ & $0.39 \pm 0.12$ & $0.43 \pm 0.09$ & $0.50 \pm 0.13$ & $0.56 \pm 0.04$ & $0.45 \pm 0.06$ & 0.41 & 0.841 \\
\hline Phosphate(mg/L) & $0.20 \pm 0.02$ & $0.74 \pm 0.28$ & $0.23 \pm 0.05$ & $0.55 \pm 0.32$ & $0.49 \pm 0.13$ & $0.19 \pm 0.04$ & 1.57 & 0.198 \\
\hline
\end{tabular}

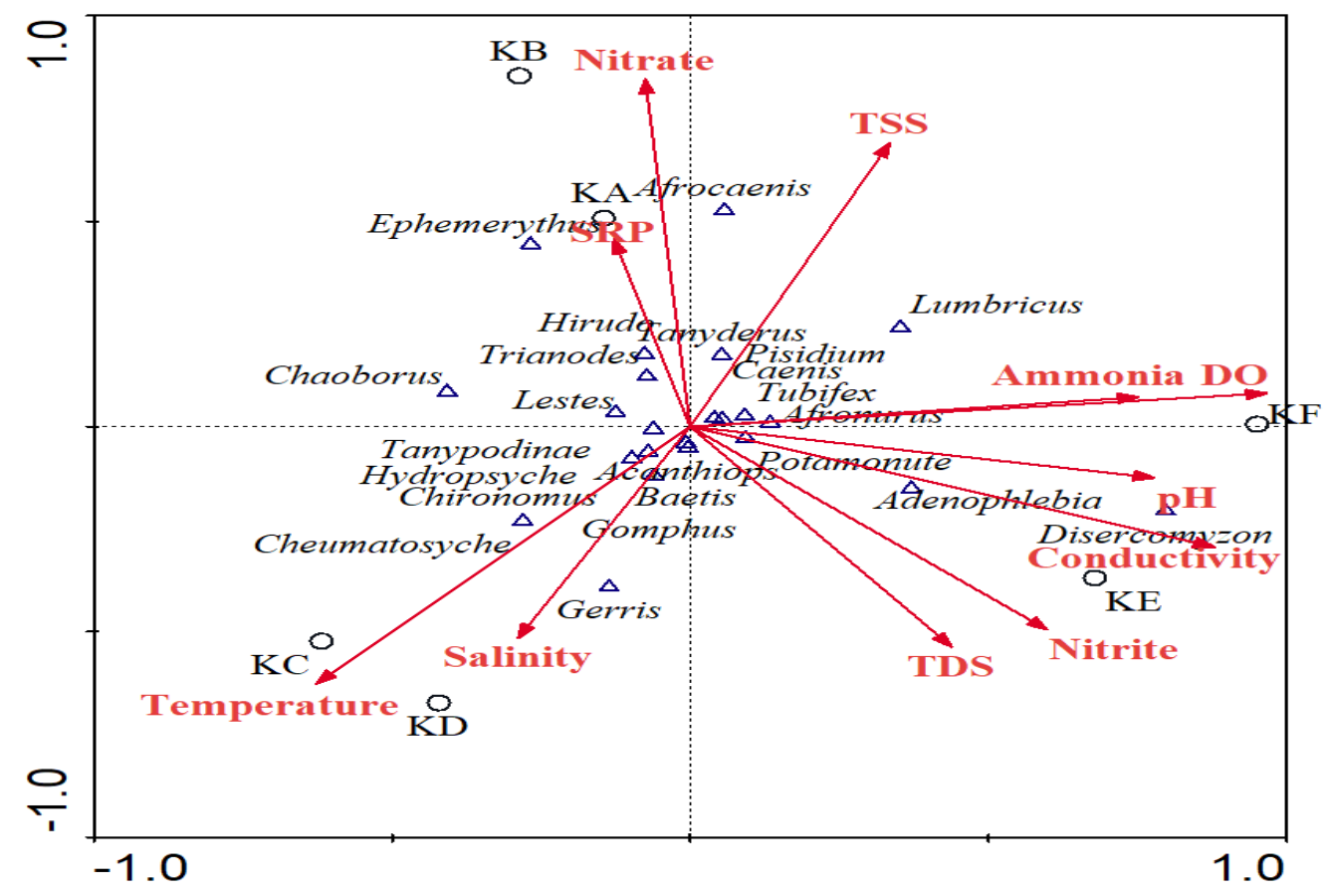

Figure 3. Canonical correspondence analysis (CCA) triplot of the macroinvertebrates with the Physico-chemical parameters in Kipsinende River.

\section{Conclusion}

Kipsinende River, just like other Kenyan rivers provide ecosystem services and livelihood for local communities that live in that place. The current study indicated that the abundance, composition, distribution, and diversity of benthic macroinvertebrates fauna of the study area was affected by deteriorating natural habitats and environmental stress. This attribute increased through human activities on the river and has negative consequences on the biotic strata of the aquatic system. This study can be used as a baseline for further studies in the area and provides information for the management and improvement of River Kipsinende and by extension to other stakeholders like ecologists, environmentalists in the Elgeyo Marakwet County, Kenya.

\section{Ethical Statement}

Not applicable.

\section{Funding Information}

This work was supported by the Intra-Africa Academic Mobility Scheme (COTRA-project) (grant 2017/2929) funded by the European Union through a fellowship to Masresha Birara Fekadu.

\section{Author Contribution}

Masresha Birara Fekadu, Simon Agembe and Clement Kiprotich Kiptum: conceptualization, designed the study, data collection and data analysis. Masresha Birara Fekadu, Simon Agembe and Minwyelet Mingist: drafting and revising of the manuscript. All authors 
commented on the manuscript and approved it for publication.

\section{Conflict of Interest}

The authors declare that they have no conflict of interest regarding the publication of this article.

\section{Acknowledgements}

This work was supported by the Intra-Africa Academic Mobility Scheme (COTRA-project) (grant 2017/2929) funded by the European Union. We appreciate the assistance by Mr. Lunaligo Lubanga and Augustine Sitati University of Eldoret during field sampling, and analysis in the laboratory. We are grateful to Mr. George Alal, University of Eldoret, for generation of the maps of the study area.

\section{References}

Alonso, Á., \& Camargo, J.A. (2010). Comparison of two methods for estimating the abundance, diversity and habitat preference of fluvial macroinvertebrates in contrasting habitats. Limnologica, 40 (1), 23-29. https://doi.org/10.1016/j.limno.2009.03.002

Andem, A.B., Udofia, U., Okorafor, K.A., Okete, J.A., \& Ugwumba, A.A.A. (2012). A study on some physical and chemical characteristics of Ona River, Apata, Ibadan South-west, Oyo State, Nigeria. European Journal of Zoological Research, 1(2), 37-46.

APHA, (1998) Standard Methods for the Examination of Water and Wastewater. 20 $0^{\text {th }}$ Edition, American Public Health Association, American Water Works Association and Water Environmental Federation, Washington DC.

Aura, C.M., Raburu, P.O., \& Herman, J. (2010). A preliminary macroinvertebrate Index of Biotic Integrity for bioassessment of the Kipkaren and Sosiane Rivers, Nzoia River basin, Kenya. Lakes \& Reservoirs: Research and Management, 15,119-128.

https://doi.org/10.1111/j.1440-1770.2010.00432.x

Bartlett-Healy, K., Unlu, I., Obenauer, P., Hughes, T., Healy, S., Crepeau, T., Farajollahi, A., Kesavaraju, B., Fonseca, \& D. Schoeler. (2012). Larval Mosquito Habitat Utilization and Community Dynamics of Aedes albopictus and Aedes japonicus (Diptera: Culicidae). Journal of Medical Entomology, 49(4), 813-824. https://doi.org/10.1603/ME11031.

Chrisoula, B.P., Vasiliki, K.G., \& Savvas, C.T. (2011). Abundance, diversity, and distribution of macrophyte communities in neighboring lakes of different trophic states and morphology in north-central GREECE, Archives of Biological Science, Belgrade, 63 (3), 125- 142. https://doi.org/10.2298/ABS1103763P.

Deborde, D.D.D., Hernandez, M.B.M., \& Magbanua, F.S. (2016). Benthic macroinvertebrate community as an indicator of stream health: the effects of land use on stream benthic macroinvertebrates. Science Diliman, 28(2), 5-26

Deepa, P., Raveen, R., Venkatesan, P., Arivoli, S., \& Samuel, T. (2016). Seasonal variations of physicochemical parameters of Korattur Lake, Chennai, Tamil Nadu, India. International Journal of Chemical Studies, 4(3), 116-123.
Dhinamala, K., Pushpalatha, M., Samuel, T., \& Raveen, R. (2015). Spatial and temporal variations in the water quality parameters of Pulicat Lake, Tamil Nadu, India. International Journal of Fisheries and Aquatic Studies, 3(2), 255-259.

Ding, N., Yang, W., Zhou, Y., González-Bergonzoni, I., Zhang, J., Chen, K., Vidal, N., Jeppesen, E. Liu., \& Z. Wang. (2017). Different responses of functional traits and diversity of stream macroinvertebrates to environmental and spatial factors in the Xishuangbanna watershed of the upper Mekong River basin, China. Science Total Environment, 574, 288-299. http://dx.doi.org/10.1016/j.scitotenv 2016.09.053.

Dipankar, G., \& Jayanta, K.B. (2015). Biomonitoring Macrophytes Diversity and Abundance for Rating Aquatic Health of an Oxbow Lake ecosystem in Ganga River Basin. American Journal of Phytomedicine and Clinical Therapeutics, AJPCT 3(10), ISSN 2321 - 2748. www.ajpct.org.

Egler, M., Buss, D.F., Moreira, J.C., \& Baptista, D.F. (2012). Influence of agricultural land-use and pesticides on benthic macroinvertebrate assemblages in an agricultural river basin in southeast Brazil. Brazilian Journal of Biology, 72(3), 437-443. https://doi.org/10.1590/S1519-69842012000300004

Elias, J.D., ljumba, J.N., Mgaya, Y.D., \& Mamboya, F.A. (2014). Study on Freshwater Macroinvertebrates of Some Tanzanian Rivers as a Basis for Developing Biomonitoring Index for Assessing Pollution in Tropical African Regions. Journal of Ecosystems, 26, 1-8. http://dx.doi.org/10.1155/2014/985389

Gerber, A. \& Gabriel, M.J.M. (2002). Aquatic- Invertebrates of South African Rivers. Institute for Water Quality Studies, Pretoria, South Africa.

GWP. (2015). Integrated Water Resources Management in Eastern Africa.Coping with 'complex' hydrology Technical Focus Paper, 9, 1-50. https://doi.org/10.13140/RG.2.1.5054.2164.

Hammer, O., Harper, D.A.T., \& Ryan, P.D. (2001). PAST: Paleontological Statistics software package for education and data analysis. Palaeontologia Electronica, 4(1), 4-99.

Kibena, J., Nhapi, I., \& Gumindoga, W. (2014). Assessing the relationship between water quality parameters and changes in land-use patterns in the Upper Manyame River, Zimbabwe. Physics and Chemistry of Earth Parts, 67, 153-163.

https://doi.org/ 10.1016/j.pce.2013.09.017.

Lindborg, R. (2015). Implications of climate and land-use change for landscape processes, biodiversity, ecosystem services, and governance. A Journal of the Human Environment, 44, 1-5. https://doi.org/ 10.1007/s13280014-0596-6.

Lobera, G., Muñoz, I., López-Tarazón, J.A., Vericat, D., \& Batalla, R.J. (2017). Effects of flow regulation on river bed dynamics and invertebrate communities in a Mediterranean river. Hydrobiologia, 784, 283-304. https://doi.org/10.1007/s10750-016-2884-6

Lozupone, C.A., Stombaugh, J.I., Gordon, J.I., Jansson, J.K., \& Knight, R. (2012). Diversity, stability and resilience of the human gut microbiota. Nature, 489 (7415), 220-230. https://doi.org/10.1038/nature11550

Magurran, A.E. (2013). Measuring biological diversity. John Wiley and Sons, New York, USA, 285-286pp.

Mandeville, S.M. (2002). Benthic Macroinvertebrates in 
Freshwaters-Taxa Tolerance Values, Metrics, and Protocols. New York State Department of Environmental Conservation.

http://chebucto.ca/Science/SWCS/SWCS.html.

Maneechan, W., \& Prommi T.O. (2015). Diversity and distribution of aquatic insects in stream of the Mae Klong watershed, western Thailand. A Journal of Entomology, (2), 1-7. https://doi.org/10.1155/2015/912451

Mariadoss, S., \& Ricardo, A. (2015). Water Quality Assessment of Piatua River Using Macroinvertebrates in Puyo, Pastaza, Ecuador. American Journal of Life Sciences, 3(3), 167-174. https://doi.org/10.11648/j.ajls.20150303.17.

Masese, F.O.N., Kitaka, J., Kipkemboi, G.M., Gettel, K. Irvine., \& M.E., McClain. (2014). Macroinvertebrate functional feeding groups in Kenyan highland streams: evidence for a diverse shredder guild. Freshwater Science, 33(2), 435450. https://doi.org/ 10.1086/675681

Mbaka, J, G., M'Erimba, C, M., Thiongo, H.K., \& Mathooko, J.M. (2014). Water and habitat quality assessment in the Honi and Naro Moru rivers, Kenya, using benthic macroinvertebrate assemblages and qualitative habitat scores. African Journal of Aquatic Science, 39(4), 361368. https://doi.org/10.2989/16085914.2014.976168.

Mbaka, K.P., Mwangi, K.J., \& Kiptum, C.K. (2017). Assessment of water quality in selected shallow wells of Keiyo Highlands, Kenya. African Journal of Science, Technology, Innovation and Development, 9(3), 329338. https://doi.org/10.1080/20421338.2017.1327476

Merritt, R.W., Cummins, K.W., \& Berg M.B. (2008). An introduction to the aquatic insects of North America. $4^{\text {th }}$ edition. Kendall/Hunt Publishing Company, Dubuque, lowa.

Morphin-Kani, K., \& Murugesan, A.G. (2014). Assessment of River Water Quality Using Macroinvertebrate Organisms as Pollution Indicators of Tamirabarani River Basin, Tamil Nadu, India. International Journal of Environmental Protection, 4(1), 1-14.

Parsons, M., Thoms, M.C., Flotemersch, J., \& Reid, M. (2016). Monitoring the resilience of rivers as social, ecological systems: a paradigm shift for river assessment in the twenty-first century. In: Gilvear, D.J., Greenwood, M.T., Thoms, M.C., Wood, P.J. (Eds.), River Science: Research and Management for the $21^{\text {st }}$ Century. John Wiley \& Sons, Ltd., West Sussex, UK, 197-220.

Patrick, O. O., Reuben, O., Eric, O., William, O., \& Stephen, M.N. (2014). Composition, Abundance and Feeding Guilds of Macroinvertebrates in Lake Kenyatta, Kenya. International Journal of Environmental Monitoring and Analysis, 2(5), 239-243. https://doi.org/10.11648/j.ijema.20140205.12.

Pellan, L., \& Piscart, C., (2018). Macroinvertebrate identity mediates the effects of litter quality and microbial conditioning on leaf litter recycling in temperate streams. Ecosystems, 23, 2542-2553. https://doi.org/10.1002/ece3.3790

Płociennik, M., \& Karaouzas, I. (2014). The Chironomidae (Diptera) fauna of Greece: Ecological distributions and patterns, taxa list, and new records. Annales de Limnologie - International Journal of Limnology, 50(1), 19-34. https://doi.org/ 10.1051/limn/2013066.

Prommi, T., \& Payakka, A. (2015). Aquatic insect biodiversity and water quality parameters of streams in Northern Thailand. Sains Malaysiana, 44(5),707-717. https://doi.org/10.17576/jsm-2015-4405-10

Raburu, P.O., Masese, F.O., \& Mulanda, C.A. (2009). Macroinvertebrate Index of Biotic Integrity (M-IBI) for monitoring rivers in the upper catchment of Lake Victoria Basin, Kenya. Aquatic Ecosystem Health and Management, 12(2), 197-205. https://doi.org/10.1080/14634980902907763

Reddy, P.R. (2014). Freshwater ecosystems and biodiversity-A Case Study of Kolleru Lake, India: A Review. Journal of India Geophysical Union, 18, 2-8.

Singh, N., \& Sharma, R.C. (2014). Some important attributes which regulate the life of macroinvertebrates: a review. International Journal of Recent Scientific Research, 5(2), 357-361.

Sundstrom, S.M., Eason, T., Nelson, R.J., Angeler, D.G., Barichievy, C., Garmestani, A.S., Graham, N.A., Granholm, D., Gunderson, L., Knutson, M., \& Nash, K.L. (2017). Detecting spatial regimes in ecosystems. Ecology Letters, 20(1), 19-32. https://doi.org/10.1111/ele.12709.

Upen, D., \& Sarada, K.S. (2015). Ecological studies of macrophytes of two major wetlands of the Nalbari district of Assam, India. New York Science Journal, 8(1), 67-75. http://www.sciencepub.net/newyork.

Vincy, M.V., Rajan, B., \& Kumar, P.A.P. (2012). Water quality assessment of a tropical wetland ecosystem with special reference to backwater tourism, Kerala, South India. International Research Journal of Environmental Science, 1(5), 62-68.

Ziajahromi, S., Kumar, A., Neale, P.A., \& Leusch, F.D. (2018). Environmentally relevant concentrations of polyethylene microplastics negatively impact the survival, growth and emergence of sediment-dwelling invertebrates. Environmental Pollution, 236, 425-431. 